\title{
RESPON KEBIJAKAN FISKAL TERHADAP SIKLUS BISNIS: STUDI KABUPATEN/KOTA DI INDONESIA TAHUN 2005-2016
}

\author{
Yusuf Munawar1, \\ Universitas Katolik Parahyangan
}

\begin{abstract}
Increasing role of regional government in the era of decentralization and increasing usage of fiscal instruments to influence the economy, bring up the view that fiscal policy ideally should be able to become an economic stabilizer or known as countercyclical fiscal policy. However, in practice, the pattern of government fiscal policy against business cycles is procyclical or follows a pattern of business cycles. This study aims to assess the response of fiscal policy in in the context of regional government expenditures, revenues, as well as fiscal balance transfer against business cycle in Indonesia. The GMM method used to estimate parameters in the model. Data in this research consist of 434 districts/cities in Indonesia for 2005-2016 period. The estimation result shows that fiscal policy response in the form of expenditure, income, and fiscal balance transfer against business cycle tends to be procyclical. The procyclical pattern from expenditure and revenues side is influenced by the main component of revenue district/city government which is still dominated by the fiscal balance transfer. Regression results show that the fiscal balance transfer tend to be procyclical pattern against business cycle so that fiscal policy pursued by the regional government has a procyclical pattern as well.
\end{abstract}

Keywords: Fiscal Policy, business cycle, countercyclical, procylical, acyclical

\begin{abstract}
ABSTRAK
Seiring dengan semakin meningkatnya peran pemerintah daerah pada era desentralisasi serta penggunaan instrumen fiskal untuk mempengaruhi perekonomian, memunculkan pandangan bahwa kebijakan fiskal idealnya harus mampu untuk menjadi penstabil ekonomi atau dikenal dengan kebijakan fiskal countercyclical. Namun, pada praktiknya seringkali pola kebijakan fiskal pemerintah terhadap siklus bisnis adalah procyclical atau mengikuti pola siklus bisnis. Penelitian ini bertujuan untuk mengetahui respon kebijakan fiskal dalam bentuk pengeluaran pemerintah, pendapatan pemerintah, serta dana perimbangan terhadap siklus bisnis di Indonesia. Metode GMM digunakan untuk mengestimasi model yang digunakan. Data yang digunakan terdiri dari data 434 kabupaten/kota di Indonesia periode 2005-2016. Dari hasil estimasi ditemukan bahwa respon kebijakan fiskal dalam bentuk pengeluaran, pendapatan, dan dana perimbangan pemerintah daerah terhadap siklus bisnis cenderung bersifat procyclical. Pola procyclical dari sisi pengeluaran dan pendapatan pemerintah daerah dipengaruhi oleh komponen utama pendukung pendapatan pemerintah kabupaten/kota yang masih didominasi oleh dana perimbangan yang diperoleh. Hasil regresi menunjukkan bahwa dana perimbangan yang diterima daerah memiliki hubungan yang bersifat procyclical terhadap siklus bisnis sehingga kebijakan fiskal yang ditempuh oleh pemerintah daerah cenderung bersifat procyclical.
\end{abstract}

Kata kunci: Kebijakan fiskal, siklus bisnis, countercyclical, procylical, acyclical Klasifikasi JEL: E62, E32

\footnotetext{
${ }^{1}$ Dosen Program Studi Ekonomi Pembangunan. email: yusuf.munawar@unpar.ac.id.
} 


\section{2 | Bina Ekonomi}

\section{PENDAHULUAN}

Pasca krisis keuangan global, kebijakan moneter dianggap kurang efektif dalam mempengaruhi perekonomian suatu negara. Hal tersebut terjadi karena berbagai negara terindikasi terjebak dalam perangkap likuiditas atau liquidity trap (Abdurohman \& Resosudarmo, 2017). Untuk itu, kebijakan fiskal seolah menawarkan solusi alternatif bagi pemerintah untuk mempengaruhi perekonomian ketika kebijakan moneter menjadi kurang efektif.

Menurut Adiningsih (2012), umumnya tujuan kebijakan fiskal berfokus pada peningkatan kesejahteraan masyarakat dengan mendorong pertumbuhan ekonomi. Seiring dengan semakin tingginya peran kebijakan fiskal dalam mempengaruhi perekonomian, memunculkan pandangan bahwa kebijakan fiskal idealnya harus mampu menjadi penstabil ekonomi. Maksud dari pernyataan ini adalah kebijakan fiskal dikatakan ideal dan efektif apabila kebijakan fiskal mampu mengimbangi pengaruh siklus bisnis atau dikenal dengan countercyclical fiscal policy. Kebijakan countercyclical ditandai dengan kebijakan fiskal ekspansif (peningkatan belanja pemerintah dan penurunan pajak) selama resesi dan kebijakan fiskal kontraktif (penurunan belanja pemerintah dan peningkatan pajak) ketika ekonomi menguat (boom).

Lane (2003) menjelaskan mengapa kebijakan fiskal countercyclical lebih baik. Pertama, dengan menerapkan kebijakan countercyclical dapat mengimbangi efek negatif dari fluktuasi ekonomi jangka pendek yang ekstrim dengan mendorong ekonomi tumbuh selama masa resesi dan mencegah ekonomi berada dalam kondisi overheat selama masa boom. Kedua, kebijakan countercyclical dianggap sebagai pilihan kebijakan yang lebih berhati-hati dalam menghadapi krisis mengingat ada ketidakpastian mengenai apakah krisis tersebut merupakan kejutan sementara atau akan berlangsung dalam periode yang cukup lama. Ketiga, kebijakan fiskal yang bersifat countercyclical merupakan komponen penstabil dari anggaran pemerintah.

Bentuk lain kebijakan fiskal yang dianggap ideal terkait dengan siklus bisnis adalah kebijakan fiskal acyclical atau tidak berkaitan dengan siklus bisnis. Kebijakan fiskal ini didasari oleh model tax smoothing. Model tax smoothing menyatakan bahwa kebijakan sebaiknya tetap netral selama siklus bisnis dan hanya merespon perubahan-perubahan yang tidak diantisipasi yang mempengaruhi hambatan anggaran pemerintah (Talvi \& Vegh, 2005).

Selain bentuk kebijakan countercyclical dan acycical, terdapat kebijakan fiskal yang bersifat procyclical. Kebijakan procyclical ditandai dengan kebijakan fiskal ekspansif (peningkatan belanja pemerintah dan penurunan pajak) selama ekonomi menguat (boom) dan kebijakan fiskal kontraktif (penurunan belanja pemerintah dan peningkatan pajak) selama resesi. Umumnya pola kebijakan fiskal yang bersifat procyclical ditemukan di negara berkembang.

Penelitian mengenai respon kebijakan fiskal terhadap siklus bisnis telah dilakukan oleh beberapa peneliti baik di negara maju (Abbot \& Jones, 2012; Gali, 1994; Rivenbark et al, 2015; Zhang, 2015; Combes et al, 2019; Rodden \& Wibbels, 2010) maupun di negara berkembang (Gavin \& Perroti, 1997; Alesina et al, 2008; Arena \& Revilla, 2009; Afdi Nizar, 2011; dan Abdurohman \& Resudarmo, 2017). Penelitian tersebut mengarahkan pada suatu pola dimana kebijakan fiskal akan sangat dipengaruhi oleh kemampuan pengelolaan keuangan pemerintah terutama dari sisi pengelolaan pendapatan. Pemerintahan yang menghadapi kendala keterbatasan anggaran pendapatan akan cenderung mengimplementasikan kebijakan fiskal yang bersifat procyclical.

Penelitian mengenai respon kebijakan fiskal terhadap siklus bisnis cenderung meneliti pada tingkatan negara atau pemerintah pusat. Penelitian pada tingkat pemerintah daerah masih 
sangat terbatas. Berdasarkan rujukan studi literatur pada penelitian ini, hanya penelitian Rivenbark et al, 2015; Zhang, 2015; Combes et al, 2019; Rodden \& Wibbels, 2010; Abbot \& Jones, 2012; serta Arena \& Revilla, 2009 yang meneliti mengenai respon kebijakan fiskal terhadap siklus bisnis pada tingkatan pemerintah daerah. Padahal, dengan semakin didorongnya peran pemerintah daerah dalam mempengaruhi perekonomian, literatur dan studi atas kemampuan pemerintah daerah dalam mengimplementasikan kebijakan fiskal yang bersifat countercyclical semakin diperlukan.

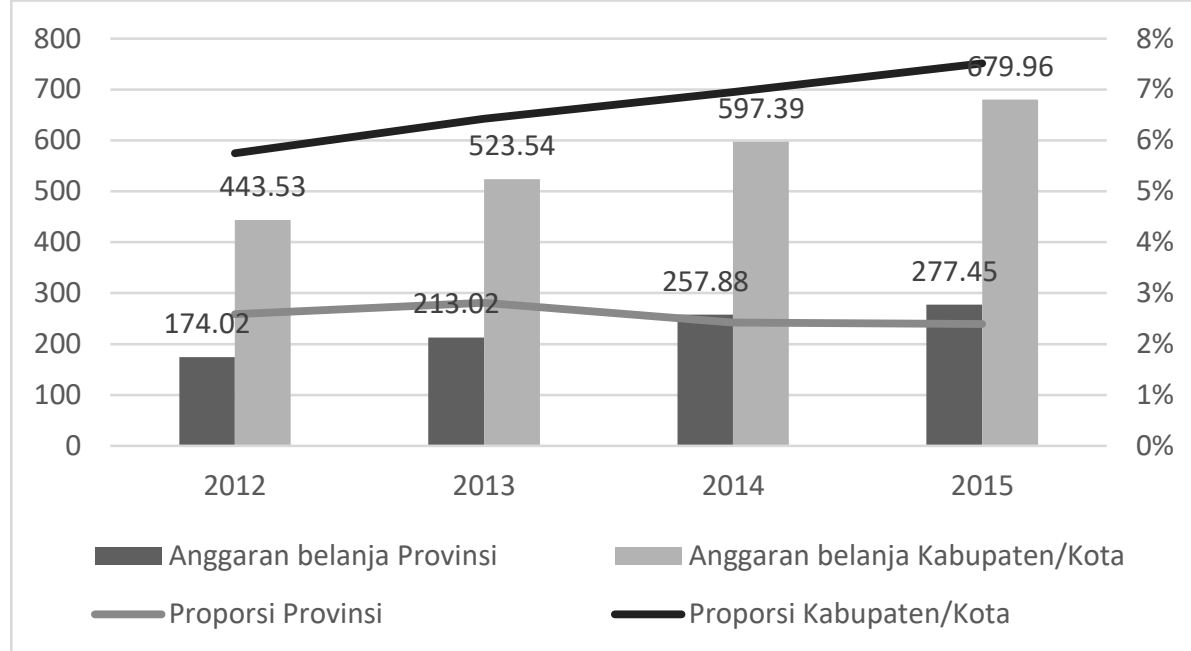

Gambar 1. Anggaran Belanja Pemerintah Provinsi dan Kabupaten/Kota Sumber : Kementerian Keuangan (diolah)

Dalam konteks Indonesia, sejak tahun 2004, pemerintah telah menerapkan kebijakan desentralisasi fiskal. Seiring dengan adanya kebijakan desentralisasi tersebut, peran pemerintah daerah dalam mempengaruhi perekonomian semakin meningkat. Pada gambar 1 ditunjukkan bahwa besaran belanja pemerintah daerah (Provinsi dan Kabupaten/Kota) terus mengalami peningkatan baik dari sisi jumlah anggarannya maupun rasionya terhadap PDRB. Dari sisi jumlah, besaran anggaran belanja pemerintah kabupaten/kota hampir mencapai tiga kali lipat dari pengeluaran pemerintah Provinsi. Begitupun dengan rasio anggaran belanja terhadap PDRB, rasio anggaran belanja pemerintah kabupaten/kota masih lebih tinggi dibandingkan dengan pemerintah provinsi dimana rasio anggaran belanja pemerintah kabupaten/kota mencapai lebih dari 5\% setiap tahunnya. Hal ini menunjukkan bahwa pada era desentralisasi, peran pemerintah kabupaten/kota terhadap perekonomian masih lebih tinggi dibandingkan dengan peran pemerintah provinsi yang ditunjukkan dengan rasio anggaran belanja terhadap PDRB.
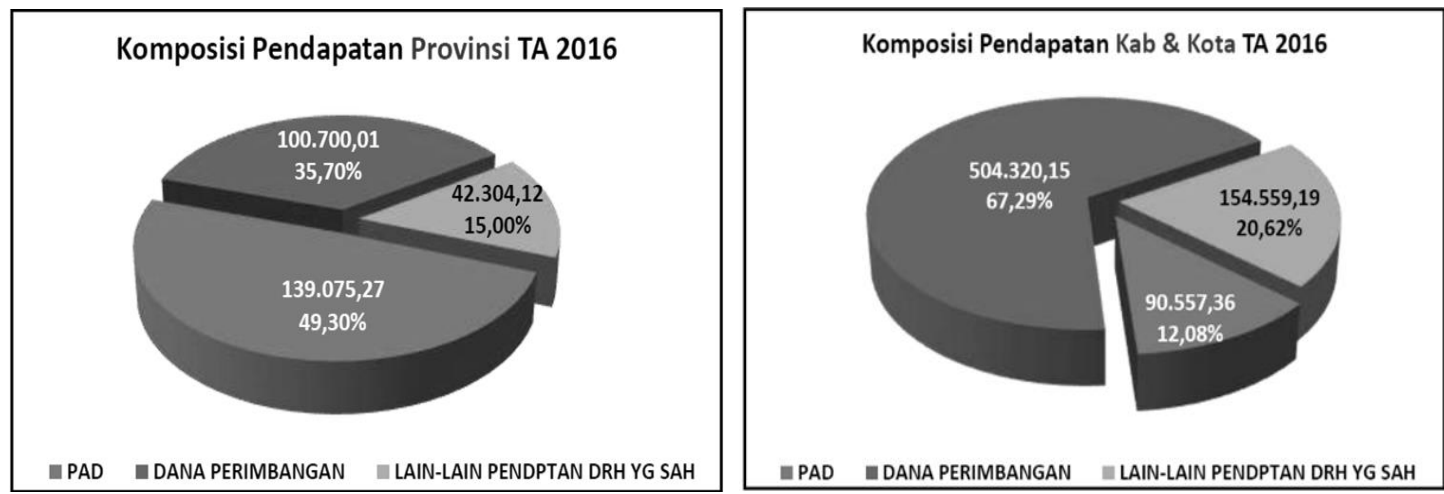

Gambar 2. Komposisi Pendapatan Pemerintah Provinsi dan Kabupaten/Kota 
Sementara itu, dari sisi pendapatan (Gambar 2), pemerintah daerah kabupaten/kota memiliki komposisi anggaran pendapatan yang terbatas dimana lebih dari 50\% pendapatan pemerintah kabupaten/kota berasal dari dana perimbangan yang diterima dari pemerintah pusat. Untuk provinsi, komposisi terbesar dalam anggaran pendapatan provinsi merupakan Pendapatan Asli Daerah (PAD) yaitu sebesar 49.30\%. Hal ini berbeda jauh dimana PAD kabupaten/kota hanya $12.08 \%$ dari anggaran pendapatan kabupaten/kota.

Menurut para ekonom Keynesian, idealnya kebijakan fiskal yang diambil oleh pemerintah (pusat maupun daerah) bersifat countercyclical. Namun, dalam beberapa literatur terutama untuk negara berkembang, kecenderungan yang terjadi adalah kebijakan fiskal yang ditempuh oleh pemerintah bersifat procyclical. Pertanyaan yang muncul selanjutnya adalah bagaimana respon kebijakan fiskal terhadap siklus bisnis dalam konteks Indonesia terutama pada tingkatan pemerintah daerah? Untuk itu, penelitian ini bertujuan untuk mengetahui bagaimana kebijakan fiskal yang diimplementasikan oleh pemerintah daerah di Indonesia dalam merespon siklus bisnis yang terjadi.

\section{METODE DAN DATA}

Umumnya terdapat dua pendekatan untuk menguji respon kebijakan fiskal terhadap siklus bisnis yaitu correlation based approaches dan regression based approaches. Pengujian mengenai hubungan kebijakan fiskal dengan siklus bisnis dengan menggunakan pendekatan korelasi dapat menimbulkan kesimpulan yang keliru dikarenakan data mungkin memiliki tingkat volatilitas yang berbeda-beda (Forbes and Rigobon, 2002; sebagaimana dikutip dari Abdurohman \& Resosudarmo, 2017). Pendekatan regresi data panel digunakan dalam penelitian ini untuk mengetahui fenomena respon kebijakan fiskal terhadap siklus bisnis di Indonesia.

Pada penelitian ini, ingin diketahui bagaimana kebijakan fiskal pada level pemerintah daerah merespon siklus bisnis yang terjadi. Kebijakan fiskal yang dimaksud dikelompokan menjadi tiga komponen utama, yaitu: 1). Dari sisi pengeluaran; 2). Dari sisi pendapatan; 3). Dari sisi transfer pemerintah pusat yang diterima oleh daerah. Untuk itu, model yang digunakan pada penelitian ini terdiri dari tiga persamaan yang diadopsi dari model Arena \& Revilla (2009):

$$
\begin{aligned}
& \Delta g_{i t}=\alpha_{1 i}+\alpha_{2 t}+\alpha_{3} \Delta g_{i, t-1}+\alpha_{4} \Delta y_{i, t}+\alpha_{5} \Delta y_{i, t-1}+\varepsilon_{i, t} \\
& \Delta r e v_{i t}=\alpha_{1 i}+\alpha_{2 t}+\alpha_{3} \Delta r e v_{i, t-1}+\alpha_{4} \Delta y_{i, t}+\alpha_{5} \Delta y_{i, t-1}+\varepsilon_{i, t} \\
& \Delta t r f_{i t}=\alpha_{1 i}+\alpha_{2 t}+\alpha_{3} \Delta t r f_{i, t-1}+\alpha_{4} \Delta y_{i, t}+\alpha_{5} \Delta y_{i, t-1}+\varepsilon_{i, t} \\
& g=\text { menunjukkan komponen belanja pemerintah untuk kabupaten/kota i pada } \\
& \text { periode } t \text {. } \\
& \text { rev = besaran penerimaan daerah dari pajak daerah untuk kabupaten/kota i pada } \\
& \text { periode } t \text {. } \\
& \text { trf = menunjukkan besaran transfer dari pusat yang diterima oleh setiap } \\
& \text { kabupaten/kota i pada periode } \mathrm{t} \text {. } \\
& y=\quad=\text { PDRB kabupaten } / \text { kota i pada periode } \mathrm{t} \text {. }
\end{aligned}
$$


$\alpha_{4}, \beta_{4}, \delta_{4}=$ menunjukkan respon kebijakan fiskal terhadap siklus bisnis.

$\checkmark$ Nilai $\alpha_{4}, \beta_{4}, \delta_{4}<0$ dan signifikan menunjukkan bahwa kebijakan fiskal cenderung bersifat countercyclical.

$\checkmark \alpha_{4}, \beta_{4}, \delta_{4}>0$ dan signifikan menunjukkan bahwa kebijakan fiskal cenderung bersifat procyclical.

$\checkmark \alpha_{4}, \beta_{4}, \delta_{4}$ yang tidak signifikan menunjukkan bahwa kebijakan fiskal cenderung acyclical.

Persamaan 1 digunakan untuk melihat respon kebijakan fiskal pemerintah daerah dalam bentuk pengeluaran/belanja daerah terhadap siklus bisnis. Persamaan 2 digunakan untuk melihat respon kebijakan fiskal pemerintah daerah dalam bentuk total penerimaan terhadap siklus bisnis. Sedangkan persamaan 3 digunakan untuk melihat respon kebijakan fiskal dalam bentuk transfer dari pemerintah pusat terhadap daerah terhadap siklus bisnis.

Parameter pada model pada persamaan 1, 2, dan 3 diestimasi dengan menggunakan Generalized Method of Moment (GMM). GMM digunakan karena estimasi terhadap parameter dengan metode OLS pada data panel model dinamis akan menghasilkan kesimpulan yang bias. Selain itu, dengan menggunakan estimator GMM dapat menghilangkan masalah endogenitas estimasi persamaan simultan pada persamaan first difference (Abbott \& Jones, 2012).

Jenis data yang digunakan dalam penelitian ini merupakan data sekunder yang diperoleh dari dari BPS (Badan Pusat Statistik) serta DJPK (Direktorat Jenderal Perimbangan Keuangan). Data yang digunakan merupakan data panel yang terdiri dari data PDRB, pengeluaran, pendapatan, dan transfer yang diterima dari 434 kabupaten/kota di Indonesia periode 20052016.

Untuk mengetahui apakah Pendapatan Asli Daerah (PAD) dapat mempengaruhi pola siklikalitas kebijakan fiskal dalam bentuk pengeluaran dan penerimaan daerah, maka akan dilakukan regresi pada dua kelompok data. Kelompok peratama (PAD 1) adalah kelompok Kabupaten/Kota yang memiliki nilai PAD diatas rata-rata PAD dari sampel yang digunakan. Sementara itu, untuk kelompok kedua (PAD 2) adalah kelompok Kabupaten/Kota yang memiliki nilai PAD dibawah rata-rata PAD dari sampel yang digunakan. Dengan melakukan pengelompokan ini dan dilakukan regresi pada model 1, 2, dan 3 terhadap dua kelompok PAD dapat menunjukkan apakah PAD dapat mempengaruhi respon kebijakan fiskal suatu daerah terhadap siklus bisnis.

\section{PEMBAHASAN}

Untuk mencapai tujuan penelitian, terlebih dahulu dilakukan pengujian terhadap stasioneritas data pada variabel-variabel yang digunakan yaitu variabel pendapatan pemerintah daerah, pengeluaran pemerintah daerah, pertumbuhan ekonomi daerah, dan transfer yang diterima oleh pemerintah daerah dalam bentuk dana perimbangan. Unit root test digunakan untuk mengidentifikasi stasioneritas data yang digunakan. Pada data panel, pembahasan mengenai unit root test masih cukup jarang dilakukan (Baltagi, 2005). Untuk itu, pada penelitian ini disajikan beberapa metode pengujian unit root test seperti disajikan pada tabel 1. 
Tabel 1. Hasil Unit Root Test

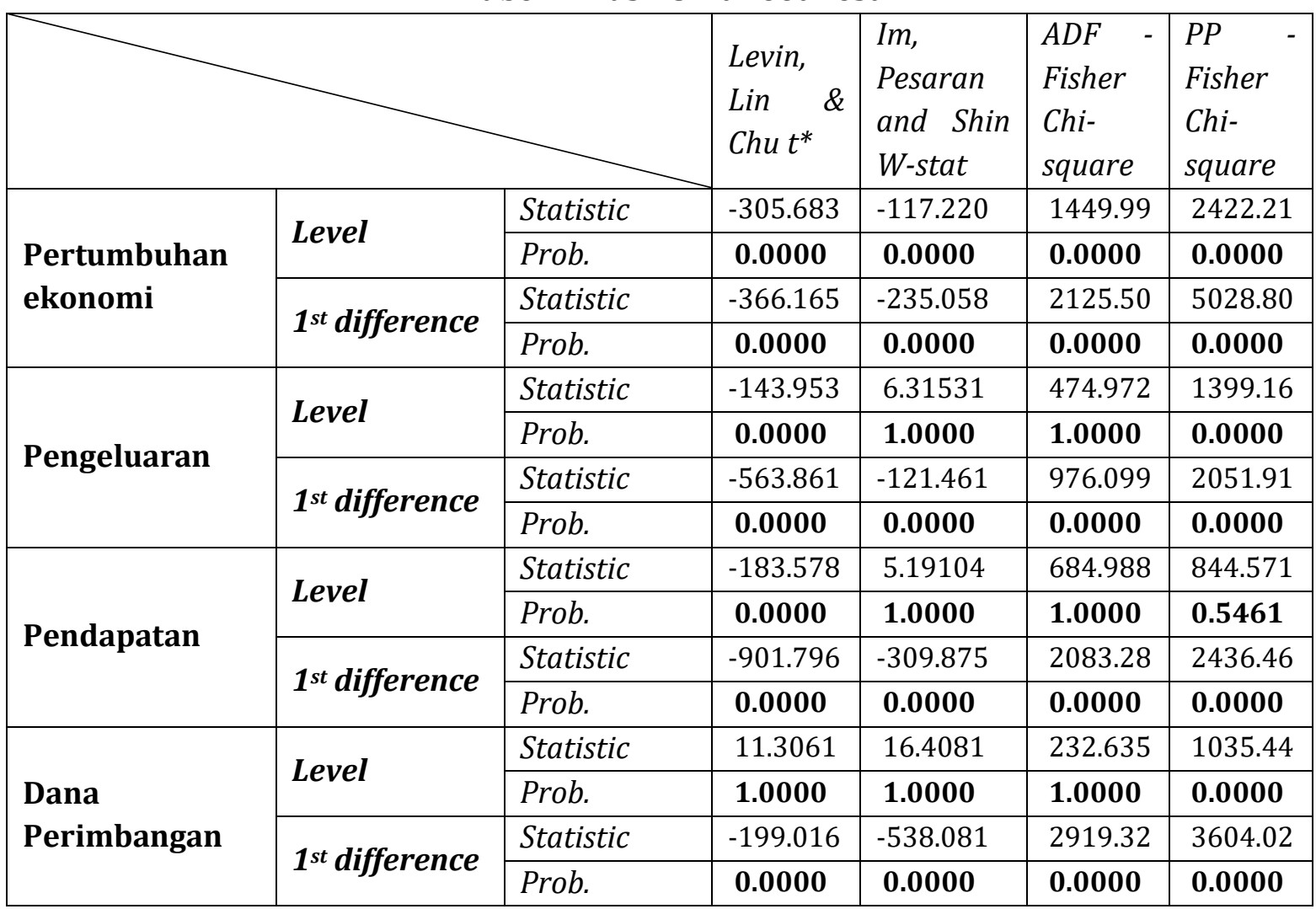

Dari hasil pengujian pada tabel 1, hampir keseluruhan variabel memiliki tingkat stasioneritas pada first difference dengan tiga metode unit root test yang digunakan. Hanya variabel pertumbuhan ekonomi (growth) yang stasioner pada tingkat level. Namun, karena keseluruhan variabel stasioner pada first difference maka data pertumbuhan ekonomi (growth) yang digunakan merupakan data first difference.

Setelah melakukan pengujian terhadap stasioneritas data, maka dilakukan pula cointegration test. Cointegration test digunakan untuk dapat mengidentifikasi adanya hubungan jangka panjang dari variabel - variabel yang digunakan dalam model. Cointegration test yang digunakan pada penelitan ini menggunakan uji Augmented Dickey-Fuller, seperti disajikan pada tabel 2 .

Tabel 2. Hasil Cointegration Test

\begin{tabular}{|c|c|c|c|c|c|}
\hline \multirow{5}{*}{$\begin{array}{l}\text { Pengeluaran dan } \\
\text { Pertumbuhan } \\
\text { Ekonomi }\end{array}$} & \multirow{2}{*}{\multicolumn{3}{|c|}{$A D F$}} & t-Statistic & Prob. \\
\hline & & & & -3.350 .106 & 0.0000 \\
\hline & \multicolumn{5}{|c|}{ Augmented Dickey-Fuller Test Equation } \\
\hline & Variable & Coefficient & Std. Error & t-Statistic & Prob. \\
\hline & RESID(-1) & -0.787110 & 0.015861 & -4.962 .417 & 0.0000 \\
\hline \multirow{6}{*}{$\begin{array}{l}\text { Pendapatan dan } \\
\text { Pertumbuhan } \\
\text { Ekonomi }\end{array}$} & \multirow{2}{*}{\multicolumn{3}{|c|}{$A D F$}} & t-Statistic & Prob. \\
\hline & & & & -1.358 .054 & 0.0000 \\
\hline & \multicolumn{5}{|c|}{ Augmented Dickey-Fuller Test Equation } \\
\hline & Variable & Coefficient & Std. Error & t-Statistic & Prob. \\
\hline & $\operatorname{RESID(-1)}$ & -0.500608 & 0.015674 & -3.193 .780 & 0.0000 \\
\hline & \multicolumn{3}{|l|}{$A D F$} & t-Statistic & Prob. \\
\hline
\end{tabular}




\begin{tabular}{|l|l|l|l|l|l|}
\hline \multirow{3}{*}{$\begin{array}{l}\text { Dana Perimbangan } \\
\text { dan Pertumbuhan }\end{array}$} & \multicolumn{4}{|c|}{$-3.730 .723$} & $\mathbf{0 . 0 0 0 0}$ \\
\cline { 2 - 6 } Ekonomi & Augmented Dickey-Fuller Test Equation & \multicolumn{3}{|c|}{} \\
\cline { 2 - 6 } & Variable & Coefficient & Std. Error & t-Statistic & Prob. \\
\cline { 2 - 6 } & RESID(-1) & -0.800657 & 0.015062 & -5.315 .693 & $\mathbf{0 . 0 0 0 0}$ \\
\hline
\end{tabular}

*Null Hypothesis: No cointegration

Cointegration test dilakukan terhadap variabel yang dimasukan dalam ketiga model (persamaan 1, 2, dan 3). Model pertama menunjukkan hubungan antara pengeluaran pemerintah dengan pertumbuhan ekonomi. Model kedua menunjukkan hubungan antara pendapatan pemerintah dengan pertumbuhan ekonomi. Model ketiga menunjukkan hubungan antara dana perimbangan yang diterima pemerintah daerah dengan pertumbuhan ekonomi. Dari hasil cointegration test seperti ditunjukkan pada tabel 2, diperoleh hasil bahwa variabel pada model pertama, model kedua, dan model ketiga memiliki hubungan kointegrasi. Hal ini menandakan bahwa variabel-variabel yang digunakan pada ketiga model tersebut memiliki hubungan jangka panjang.

Dari hasil pengujian unit root test diperoleh hasil bahwa variabel pendapatan pemerintah, pengeluaran pemerintah, pertumbuhan ekonomi bagi masing-masing daerah, dan dana perimbangan yang diperoleh oleh masing-masing daerah stasioner pada first difference. Sementara itu, dengan menggunakan pengujian cointegration test diperoleh hasil bahwa variabel - variabel yang dimasukan ke dalam model memiliki hubungan kointegrasi atau memiliki hubungan jangka panjang. Oleh karena itu, model koreksi kesalahan atau error correction model digunakan untuk mengestimasi model pada penelitian ini karena variabel yang digunakan memiliki tingkat stasioneritas pada first difference dan variabel yang digunakan pada model memiliki hubungan kointegrasi atau hubungan jangka panjang.

\subsection{Respon Pengeluaran Pemerintah Kabupaten/Kota terhadap Siklus Bisnis}

Tabel 3. Hasil Regresi Respon Pengeluaran Pemerintah Kabupaten/Kota terhadap Siklus Bisnis

\begin{tabular}{|c|c|c|c|c|c|c|}
\hline \multicolumn{7}{|c|}{ Pengeluaran Pemerintah Kabupaten/Kota } \\
\hline \multicolumn{3}{|l|}{ Keseluruhan Daerah } & \multicolumn{2}{|c|}{$P A D 1$} & \multicolumn{2}{|c|}{ PAD 2} \\
\hline Variable & Coefficient & Prob. & Coefficient & Prob. & Coefficient & Prob. \\
\hline LPENGELUARAN(-1) & 0.9206 & $0.0000^{* * *}$ & 0.8913 & $0.0000^{* * *}$ & 0.9081 & $0.0000^{* * *}$ \\
\hline LPERTUMBUHAN & -0.0124 & 0.7129 & 0.0206 & $0.0000^{* * *}$ & -0.0379 & 0.3321 \\
\hline LPERTUMBUHAN(-1) & 0.1666 & $0.0003^{* * *}$ & 0.1199 & $0.0000^{* * *}$ & -0.0554 & 0.1209 \\
\hline
\end{tabular}

PAD 1: Kelompok Kabupaten/Kota yang memiliki $\quad * * *=$ Signifikan pada $\alpha=1 \%$.

nilai PAD diatas rata-rata PAD dari sampel yang $* * \quad=$ Signifikan pada $\alpha=5 \%$.

digunakan.

* $\quad=$ Signifikan pada $\alpha=10 \%$.

PAD 2: Kelompok Kabupaten/Kota yang memiliki nilai PAD dibawah rata-rata PAD dari sampel yang digunakan.

Tabel 3 menunjukkan hasil regresi pada model pertama untuk melihat respon kebijakan fiskal dari sisi pengeluaran pemerintah kabupaten/kota terhadap siklus bisnis. Secara keseluruhan daerah kabupaten/kota, dengan menggunakan $\alpha=1 \%$, hasil regresi menunjukkan 


\section{8 | Bina Ekonomi}

adanya pola kebijakan fiskal dari segi pengeluaran daerah yang bersifat procyclical dalam jangka pendek. Hubungan jangka pendek yang bersifat procyclical ditunjukkan oleh coefficient yang bernilai positif $(0,1666)$ dan signifikan dimana (dalam jangka pendek) ketika pertumbuhan ekonomi naik sebesar $1 \%$ maka pengeluaran pemerintah akan naik sebesar $0.17 \%$. Sedangkan dalam jangka panjang, hubungan antara pengeluaran pemerintah sebagai respon terhadap siklus bisnis bersifat acyclical (cenderung tidak ada hubungan). Hubungan jangka panjang yang bersifat acyclical ditunjukkan oleh coefficient yang bernilai negatif $(-0,0124)$ dan tidak signifikan sehingga menunjukkan kecenderungan bahwa kebijakan fiskal dari sisi pengeluaran tidak memiliki hubungan dengan siklus bisnis. Pola hubungan jangka pendek yang bersifat procyclical ini juga menunjukkan bahwa dalam penentuan anggaran belanja daerah yang termuat dalam APBD akan dipengaruhi oleh pertumbuhan ekonomi pada satu tahun sebelumnya dan tidak dipengaruhi oleh pertumbuhan ekonomi jangka panjang.

Sementara itu, untuk mengetahui pola respon kebijakan fiskal di daerah dengan mempertimbangkan pendapatan asli daerah, pada penelitian ini kabupaten/kota dikelompokan ke dalam 2 kelompok yaitu kelompok dengan PAD diatas rata-rata PAD sampel yang digunakan, serta kelompok dengan PAD dibawah rata-rata PAD sampel. Dengan menggunakan $\alpha=1 \%$, pada kelompok pertama atau pada kelompok dengan PAD diatas rata-rata diperoleh hasil bahwa dalam jangka pendek dan jangka panjang memiliki kecenderungan memiliki pola kebijakan fiskal dari sisi pengeluaran yang bersifat procyclical atau mengikuti pola siklus bisnis. Hal ini ditunjukkan dengan nilai coefficient positif (0,0206 pada jangka panjang; dan 0,1199 pada jangka pendek) pada kelompok PAD di atas rata rata. Pada jangka panjang, ketika perekonomian meningkat sebesar $1 \%$ maka pengeluaran pemerintah akan naik sebesar $0.02 \%$. Sementara itu, pada jangka pendek, ketika perekonomian meningkat sebesar $1 \%$ maka pengeluaran pemerintah akan naik sebesar $0.12 \%$. Sedangkan pada pada kelompok PAD di bawah rata-rata, dengan menggunakan $\alpha=1 \%$ diperoleh hasil regresi yang memiliki coefficient negatif $(-0,0379$ dalam jangka panjang; $-0,0554$ dalam jangka pendek) dan tidak signifikan sehingga dapat disimpulkan pada kelompok ini pengeluaran pemerintah cenderung tidak memiliki hubungan dengan siklus bisnis atau bersifat acyclical. Pada kelompok dengan PAD di bawah rata-rata, kebijakan pengeluaran pemerintah yang diambil cenderung akan mengikuti pola pengeluaran pada tahun sebelumnya dan tidak mengikuti pola siklus bisnis yang terjadi.

Berdasarkan pemodelan, baik secara keseluruhan maupun dengan memperhatikan variabel pendapatan asli daerah, ditunjukkan bahwa pola pengeluaran pemerintah cenderung bersifat procyclical terhadap siklus bisnis. Pola procyclical ini cenderung dipengaruhi oleh kemampuan pendapatan daerahnya. Hal ini ditunjukkan dengan hasil regresi dan data bahwa baik kelompok daerah yang memiliki PAD diatas rata-rata maupun PAD dibawah rata-rata masih sangat tergantung pada pendapatan yang berasal dari transfer dari pemerintah pusat. Hal ini sejalan dengan penelitian Rivenbark et al (2015) serta Combes et al (2019) yang menekankan bahwa sisi pendapatan yang akan mempengaruhi pola pengeluaran pemerintah.

\subsection{Respon Pendapatan Pemerintah Kabupaten/Kota terhadap Siklus Bisnis}

Tabel 4. Hasil Regresi Respon Pendapatan Pemerintah Kabupaten/Kota terhadap Siklus Bisnis

\begin{tabular}{|c|c|c|c|c|c|c|}
\hline \multicolumn{7}{|c|}{ Pendapatan Pemerintah Kabupaten/Kota } \\
\hline \multicolumn{3}{|c|}{ Keseluruhan Daerah } & \multicolumn{2}{|c|}{ PAD 1} & \multicolumn{2}{|c|}{ PAD 2} \\
\hline Variable & Coefficient & Prob. & Coefficient & Prob. & Coefficient & Prob. \\
\hline LPENDAPATAN $(-1)$ & 0.8618 & $0.0000^{* * *}$ & 0.6787 & $0.0000^{* * *}$ & 0.6643 & $0.0000^{* * *}$ \\
\hline
\end{tabular}




\begin{tabular}{|l|l|l|l|l|l|l|}
\hline LPERTUMBUHAN & 0.1086 & 0.3194 & -0.0439 & $0.0000^{* * *}$ & -0.2208 & $0.0027^{* * *}$ \\
\hline LPERTUMBUHAN(-1) & 0.2606 & $0.0230^{* *}$ & 0.0988 & $0.0000^{* * *}$ & -0.1249 & $0.0233^{* *}$ \\
\hline
\end{tabular}

PAD 1: Kelompok Kabupaten/Kota yang memiliki nilai PAD diatas rata-rata PAD dari sampel yang digunakan.

$$
\begin{aligned}
& * * * \quad=\text { Signifikan pada } \alpha=1 \% . \\
& * * \quad=\text { Signifikan pada } \alpha=5 \% . \\
& * \quad=\text { Signifikan pada } \alpha=10 \%
\end{aligned}
$$

PAD 2: Kelompok Kabupaten/Kota yang memiliki nilai PAD dibawah rata-rata PAD dari sampel yang digunakan.

Tabel 4 menunjukkan hasil regresi pada model kedua untuk melihat respon pendapatan pemerintah kabupaten/kota terhadap siklus bisnis. Secara keseluruhan daerah, dengan menggunakan $\alpha=5 \%$, hasil regresi menunjukkan adanya pola kebijakan fiskal dari segi pendapatan daerah yang bersifat countercyclical dalam jangka pendek. Sedangkan dalam jangka panjang, hubungan antara pendapatan pemerintah sebagai respon terhadap kebijakan fiskal bersifat acyclical (cenderung tidak ada hubungan). Hubungan jangka panjang yang bersifat acyclical ditunjukkan oleh coefficient yang bernilai positif $(0,1086)$ dan tidak signifikan sehingga kebijakan fiskal dari sisi pendapatan menunjukkan kecenderungan tidak memiliki hubungan dengan siklus bisnis. Hubungan jangka pendek yang bersifat countercyclical ditunjukkan oleh coefficient yang bernilai positif $(0,2606)$ dan signifikan dimana (pada hubungan dalam jangka pendek) ketika pertumbuhan ekonomi naik sebesar 1\% maka pendapatan pemerintah akan naik sebesar $0.26 \%$. Sementara itu, dengan mengelompokkan kabupaten/kota kedalam 2 kelompok yaitu kelompok dengan PAD di atas rata-rata PAD sampel yang digunakan, serta kelompok dengan PAD di bawah rata-rata PAD sampel diperoleh hasil sebagai berikut:

- $\quad$ Dengan menggunakan $\alpha=1 \%$, pada kelompok dengan PAD di atas rata-rata memiliki kecenderungan memiliki pola kebijakan fiskal yang bersifat procyclical dalam jangka panjang. Hal ini ditunjukkan dengan nilai coefficient negatif pada kelompok PAD diatas rata-rata dengan nilai coefficient sebesar -0.0439 yang berarti bahwa ketika perekonomian meningkat sebesar $1 \%$ maka pendapatan pemerintah akan menurun sebesar $0.044 \%$. Namun, dalam jangka pendek, kelompok dengan PAD di atas ratarata dapat menerapkan pola kebijakan yang bersifat countercyclical. Hal ini ditunjukkan dengan nilai coefficient positif dan signifikan dengan nilai sebesar 0,0988 yang berarti bahwa ketika perekonomian meningkat sebesar $1 \%$ maka pendapatan pemerintah akan meningkat sebesar 0,099\%.

- $\quad$ Sementara itu, dengan menggunakan $\alpha=5 \%$, pada kelompok dengan PAD di bawah rata-rata, memiliki kecenderungan pola kebijakan fiskal yang bersifat procyclical dalam jangka pendek dan dalam jangka panjang. Hal ini ditunjukkan dengan nilai coefficient negatif pada kelompok PAD di bawah rata-rata dengan nilai coefficient sebesar -0.2208 (jangka panjang) dan -0,1249 (jangka pendek). Koefisien tersebut menujukan bahwa dalam jangka panjang, ketika perekonomian meningkat sebesar 1\% maka pendapatan pemerintah kabupaten/kota akan turun sebesar $0.22 \%$. Sementara itu, pada jangka pendek, ketika perekonomian meningkat sebesar $1 \%$ maka pendapatan pemerintah kabupaten/kota akan turun sebesar 0,13\%. 
Kebijakan fiskal dari sisi pendapatan yang bersifat procyclical terhadap siklus bisnis cenderung lebih kuat pada kelompok daerah dengan PAD di bawah rata-rata dibandingkan dengan kelompok daerah dengan PAD di atas rata-rata. Hal ini ditunjukkan dengan lebih besarnya penurunan pendapatan pemerintah daerah ketika perekonomian meningkat sebesar $1 \%$ pada kelompok PAD di bawah rata-rata (sebesar 0.22\%) dibandingakan dengan kelompok daerah dengan PAD diatas rata-rata (sebesar 0.044\%). Temuan ini sejalan dengan temuan Arena \& Revilla (2009), Rivenbark et al (2015), Combes et al (2019), serta Rodden \& Wibbels (2010) dimana menemukan bahwa kebijakan fiskal pada level pemerintah daerah yang cenderung bersifat procyclical dipengaruhi oleh keterbatasan sumber pendapatan bagi pemerintah daerah. Pola procyclical yang muncul ini bisa ditanggulangi oleh pemerintah daerah dengan mengatur pola cadangan pendapatan (Rivenbark et al, 2015) serta pembiayaan melalui utang (Zhang, 2015)

\subsection{Respon Dana Perimbangan Pemerintah Kabupaten/Kota terhadap Siklus Bisnis}

Tabel 5. Hasil Regresi Respon Dana Perimbangan Pemerintah Kabupaten/Kota terhadap Siklus Bisnis

\begin{tabular}{|c|c|c|c|c|c|c|}
\hline \multicolumn{7}{|c|}{ Dana Perimbangan Pemerintah Kabupaten/Kota } \\
\hline \multicolumn{3}{|c|}{ Keseluruhan Daerah } & \multicolumn{2}{|c|}{ PAD 1} & \multicolumn{2}{|c|}{ PAD 2} \\
\hline Variable & Coefficient & Prob. & Coefficient & Prob. & Coefficient & Prob. \\
\hline LPERIMBANGAN(-1) & 1.1270 & $0.0000^{* * *}$ & 0.9804 & $0.0000^{* * *}$ & 1.0908 & $0.0000^{* * *}$ \\
\hline LPERTUMBUHAN & 0.2958 & $0.0000^{* * *}$ & 0.0787 & $0.0000^{* * *}$ & 0.2475 & $0.0000^{* * *}$ \\
\hline LPERTUMBUHAN(-1) & 0.0351 & 0.4664 & 0.0135 & $0.0001^{* * *}$ & -0.0310 & 0.4671 \\
\hline
\end{tabular}

PAD 1: Kelompok Kabupaten/Kota yang memiliki $\quad * * *=$ Signifikan pada $\alpha=1 \%$.

nilai PAD diatas rata-rata PAD dari sampel yang $* * \quad=$ Signifikan pada $\alpha=5 \%$.

digunakan.

* $\quad=$ Signifikan pada $\alpha=10 \%$.

PAD 2: Kelompok Kabupaten/Kota yang memiliki nilai PAD dibawah rata-rata PAD dari sampel yang digunakan.

Pendapatan pemerintah daerah pada tingkat kabupaten/kota memiliki beberapa komponen, antara lain komponen Pendapatan Asli Daerah (PAD) dan Komponen Dana Perimbangan. Tabel 5 menunjukkan hasil regresi pada model ketiga untuk melihat respon kebijakan fiskal dalam bentuk besaran dana perimbangan yang diperoleh pemerintah kabupaten/kota dalam kaitannya terhadap siklus bisnis.

Dengan menggunakan $\alpha=1 \%$, secara keseluruhan daerah, menunjukkan adanya pola kebijakan fiskal dari sisi dana perimbangan daerah yang bersifat procyclical dalam jangka panjang. Hubungan jangka panjang yang bersifat procyclical ditunjukkan oleh coefficient yang bernilai positif $(0,2958)$ dan signifikan dimana (dalam jangka panjang) ketika pertumbuhan ekonomi naik sebesar 1\% maka dana perimbangan yang diterima oleh daerah akan naik sebesar $0.3 \%$. Namun, dalam jangka pendek hubungan antara dana perimbangan dengan siklus ekonomi cenderung bersifat acyclical. Hal ini ditunjukkan oleh coefficient yang bernilai positif $(0,0351)$ dan tidak signifikan sehingga cenderung dana perimbangan tidak memiliki hubungan dengan siklus bisnis.

Sementara itu, pada kelompok dengan PAD di atas rata-rata, dengan menggunakan $\alpha=1 \%$, diperoleh hasil bahwa respon kebijakan fiskal dalam bentuk dana perimbangan yang diperoleh kabupaten/kota pada kelompok PAD di atas rata-rata memiliki kecenderungan bersifat 
procyclical atau mengikuti pola siklus bisnis baik pada jangka pendek maupun pada jangka panjang. Pada jangka panjang, nilai coefficient positif sebesar 0.0787 yang berarti bahwa ketika perekonomian meningkat sebesar $1 \%$ maka dana perimbangan yang diperoleh oleh pemerintah kabupaten/kota akan naik sebesar $0.08 \%$. Sementara itu, pada jangka pendek nilai coefficient positif sebesar 0.0135 yang berarti bahwa ketika perekonomian meningkat sebesar 1\% maka dana perimbangan yang diperoleh oleh pemerintah kabupaten/kota akan naik sebesar $0.014 \%$.

Sedangkan pada pada kelompok PAD di bawah rata-rata, dengan menggunakan $\alpha=1 \%$, hasil regresi menunjukkan hasil coefficient positif dan signifikan pada jangka panjang sehingga kesimpulan yang diperoleh adalah dana perimbangan yang diperoleh pemerintah daerah pada kelompok ini juga bersifat procyclical atau mengikuti pola siklus bisnis pada jangka panjang. Hal ini ditunjukkan dengan nilai coefficient positif pada kelompok PAD dibawah rata-rata sebesar 0.2475 yang berarti bahwa ketika perekonomian meningkat sebesar $1 \%$ maka dana perimbangan yang diperoleh oleh pemerintah kabupaten/kota akan naik sebesar $0.25 \%$. Pengaruh dana perimbangan terhadap siklus bisnis pada kelompok PAD di bawah rata-rata cenderung lebih kuat dibandingkan pada kelompok PAD di atas rata-rata. Hal ini ditunjukkan oleh besarnya nilai perubahan dana perimbangan yang diperoleh oleh kelompok PAD di bawah rata-rata dimana ketika perekonomian tumbuh $1 \%$ maka dana perimbangan meningkat sebesar $0.25 \%$. Sementara itu, pada kelompok dengan PAD di atas rata-rata, ketika perekonomian tumbuh sebesar $1 \%$ maka dana perimbangan yang diperoleh meningkat sebesar $0.09 \%$.

Berdasarkan pada pemodelan dari sisi pendapatan dan kaitannya terhadap transfer dari pemerintah pusat, ditunjukkan bahwa kecenderungan pemerintah daerah memiliki pola kebijakan fiskal yang bersifat procyclical. Hal ini terutama dipengaruhi oleh besarnya proporsi dana perimbangan terhadap total pendapatan daerah. Pada tahun 2016, proporsi dana perimbangan terhadap komposisi pendapatan daerah kabupaten/kota adalah sekitar 67\%. Pola dana perimbangan yang cenderung bersifat procyclical atau mengikuti pola siklus bisnis diduga memberikan pengaruh terhadap pola procyclical kebijakan fiskal pemerintah kota/kabupaten baik dari sisi pendapatan maupun dari sisi pengeluaran pemerintah. Besarnya pengaruh dana perimbangan lebih tinggi terhadap kelompok dengan PAD dibawah rata-rata yang menunjukkan bahwa adanya hubungan erat antara dana perimbangan dengan anggaran pendapatan dan belanja daerah. Hal ini juga sejalan dengan temuan Arena \& Revilla (2009) serta Zhang (2015) yang menemukan bahwa pola kebijakan fiskal yang bersifat procyclical ini berkaitan dengan keterbatasan anggaran pendapatan dan ketergantungannya atas besaran transfer pemerintah pusat ke daerah.

\section{SIMPULAN}

Dari hasil estimasi dan pembahasan mengenai hubungan kebijakan fiskal dan siklus ekonomi, dapat ditarik kesimpulan bahwa kebijakan fiskal pada tingkatan pemerintah kabupaten/kota memiliki pola yang cenderung bersifat procyclical baik dilihat dari sisi pendapatan maupun dari sisi pengeluaran. Hal ini melengkapi temuan sebelumnya dalam konteks Indonesia yaitu penelitian Afdi Nizar (2011) dan Abdurohman \& Resudarmo (2017) yang menemukan bahwa di Indonesia kebijakan fiskal pemerintah pusat cenderung bersifat procyclical terutama untuk komponen anggaran belanja.

Pola procyclical dari sisi pengeluaran dan pendapatan pemerintah daerah kabupaten/kota 


\section{2 | Bina Ekonomi}

dipengaruhi oleh adanya keterbatasan akses keuangan. Hal ini ditunjukkan oleh komponen utama pendapatan pemerintah kabupaten/kota yang masih didominasi oleh dana perimbangan. Berdasarkan hasil regresi, dana perimbangan yang diterima daerah memiliki hubungan yang bersifat procyclical sehingga kebijakan fiskal baik dari sisi pengeluaran maupun pendapatan juga memiliki pola procyclical.

Untuk menanggulangi pola procyclical yang muncul ini pemerintah bisa menanggulangi dengan mengatur pola cadangan pendapatan serta mencari alternatif pendapatan pemerintah lainnya seperti pembiayaan melalui utang disamping dengan usaha pemerintah daerah untuk memaksimumkan Pendapatan Asli Daerah. Dengan memanfaatkan potensi pendapatan asli daerah yang dimiliki dapat mengurangi ketergantungan terhadap dana perimbangan yang diterima dari pusat.

Penelitian ini memiliki keterbatasan dimana hanya memasukan kondisi makroekonomi dan tidak memasukan aspek politik, misalnya bagaimana hubungan antara pemerintah daerah dengan pemerintah pusat berdasarkan kepentingan politisnya. Oleh karena itu, penelitian selanjutnya bisa memasukan aspek politik tersebut untuk meneliti mengenai siklikalitas kebijakan fiskal yang terjadi dalam konteks pemerintah daerah. 


\section{DAFTAR PUSTAKA}

Abbott, A., \& Jones, P. (2012). Procyclical state spending in the USA: the impact of political ideology. Public Finance and Management, 12(3), 261-280.

Abdurohman, \& Resosudarmo, B. P. (2017). The Behavior Of Fiscal Policy In Indonesia In Response To Economic Cycles. The Singapore Economic Review, 62(02), 377-401.

Adiningsih, S. (2012). Koordinasi dan interaksi kebijakan fiskal-moneter: tantangan ke depan. Yogyakarta: Kanisius.

Afdi Nizar, M. (2011). Siklikalitas kebijakan fiskal di Indonesia. Jurnal Keuangan dan Moneter, $14(1)$.

Alesina, A., Tabellini, G., \& Campante, F. R. (2008). Why is fiscal policy often procyclical? Journal of the European Economic Association, 6(5), 1006-1036.

Arena, M., \& Revilla, J. E. (2009). Pro-cyclical fiscal policy in Brazil evidence from the states. World Bank Policy Research Working Paper 5144 (December). Washington DC: World Bank.

Baltagi, B. H. (2005). Econometric analysis of panel data (3 ed.). West Sussex: John Wiley \& Sons Ltd.

Combes, J. L., Renard, M. F., \& Tapsoba, S. J. A. (2019). Provincial public expenditure in China: a tale of pro-cyclicality. Economic Change and Restructuring, 52(1), 19-41.

Gali, J. (1994). Government size and macroeconomic stability. European Economic Review (38), 117- 132.

Gavin, M., \& Perotti, R. (1997). Fiscal policy in latin america. NBER macroeconomics annual, 12, 11-61.

Lane, Philip R. (2003). Cyclical behaviour of fiscal policy: evidence from the OECD. Journal of Public Economics, 87(12), 2661 - 2675.

Rivenbark, W. C., Roenigk, D. J., \& Noto, L. (2015). Exploring countercyclical fiscal policy in local government: Moving beyond an aggregated approach. International Journal of Public Administration, 38(2), 75-81.

Rodden, J., \& Wibbels, E. (2010). Fiscal decentralization and the business cycle: An empirical study of seven federations. Economics \& Politics, 22(1), 37-67.

Talvi, E., \& Vegh, C. (2005). Tax base variability and procyclical fiscal policy. Journal of Economic Development, 78 (1), 156-190.

Zhang, P. (2015). Facing fiscal crisis: Managing counter-cyclical debt financing of the state and local governments. Journal of Public Budgeting, Accounting \& Financial Management, 27(4). 523-545. 